\title{
Needlestick and sharps injuries among housekeeping workers in hospitals of Shiraz, Iran
}

Parvin Lakbala ${ }^{*}$, Farbood Ebadi Azar ${ }^{2}$ and Hajeb Kamali ${ }^{3}$

\begin{abstract}
Background: Needlestick and sharps injuries (NSSIs) are one of the major risk factors for blood-borne infections (BBPs) at healthcare facilities. This study examines the current prevalence of NSSIs among housekeeping workers engaged in the handling and disposal of biomedical waste (BMW) at government and private hospitals in Shiraz, Iran, and furthermore, explores strategies for preventing these injuries.

Findings: Using a cross-sectional study design, NSSI's and associated protective measures for housekeeping workers throughout hospitals in Shiraz were evaluated from 2009 onwards. Using a questionnaire, data was collected for 92 workers who had engaged directly with BMW. Data was analyzed using Chi-square, student t-test and where appropriate, SPSS version 12. $90.2 \%$ of housekeeping workers were warned of the dangers associated with waste, $87.5 \%$ in government and $93.2 \%$ in private hospitals $(P=0.0444) .83 .7 \%$ had attended educational programs on biomedical waste (BMW) management and injury prevention at their hospital in the preceding year. $16.3 \%$ had not been trained in biomedical waste management $(P=0.0379)$ and $88.9 \%$ had a sufficient supply of safety wear.

Conclusions: NSSIs are a common risk factor for infection among health care workers within hospitals in Iran. For the effective prevention of these injuries, health boards and hospital trusts need to formulate strategies to improve the working conditions of health care workers, discourage the excessive use of injections, and increase their adherence to universal precautions.
\end{abstract}

Keywords: Needlestick and sharps injuries, Biomedical waste, Blood-borne pathogens, Housekeeping work

\section{Findings}

Needlestick injuries are an important and common occupational injury amongst healthcare workers and have a significant impact on the morbidity and mortality of these workers through the transmission of BBP [1,2]. Biomedical or Healthcare waste is a term used for all waste that arises in healthcare establishments. Syringes used in hospital are sharps, one of the types of risk waste [3]. The highest risk groups are doctors, nurses, healthcare auxiliaries, hospital maintenance personnel and patients in healthcare establishments [4]. Among the 35 million health care workers worldwide, three million experience needlestick and sharps injuries (NSSIs) every year [5].

\footnotetext{
* Correspondence: parvin_lakbala@yahoo.com

${ }^{1}$ Medical Record and Health Information Technology, Hormozgan University of Medical Science, Bandar Abbas 79168319, Iran

Full list of author information is available at the end of the article
}

More than 100,000 NSSI are reported in UK hospitals annually[6], posing a considerable risk for the transmission of more than 20 kinds of blood-borne pathogens, including hepatitis $B$ virus (HBV), hepatitis $\mathrm{C}$ virus $(\mathrm{HCV})$, and human immunodeficiency virus (HIV) [2]. The World Health Organization has estimated that exposure to sharps in the workplace accounts for $40 \%$ of infections with HBV and HCV and 2-3 \% of HIV infections among health care workers [7]. These occupationally related infections have implications on the psychological and physical wellbeing of those they affect but also have a socio-economic impact and are a financial burden for accident and insurance institutions. In recognition of these consequences, prevention measures have been the focus of hazard reduction for health care professionals [8].

The major activities causing needle stick injuries are administering injections, blood sampling, recapping needles, needles disposal, handling non-biological waste and dirty linen (downstream injuries) and during the transfer 
of bodily fluid from a syringe to a specimen container (such as a vacuum tube) [9]. Safety practice has a serious role in safety and health maintenance of health care workers [10].

The overall rate of transmission of HBV among susceptible HCW without post-exposure prophylaxis or up to date vaccination has been estimated as between $6 \%$ and $30 \%$ [11] although estimated rates of HBV infection among HCW in the U.S.A have declined since the 1980s by around $95 \%$ [12]. Potential reasons for this decline include the licensing and increasing use of an effective vaccine and changes in work practices, such as the adoption of universal precautions [11]. However, evidence from the US suggests that more than half of all sharpsrelated injuries are not reported [13]. Poor reporting of sharps-related injuries reveals a failure to appreciate the potential consequences of such injuries [14].

The purpose of this study is to evaluate needle stick and sharps injury among housekeeping workers involved in hospital waste handling and disposal. Alongside this, we also aim to assess awareness of the implications on public and environmental health relating to improper management of health care waste amongst this group as well as the use of protective and precautionary measures against NSSI.

\section{Methods}

A survey was conducted in 2009 of 92 housekeeping workers in 9 hospitals, made up of 4 government and 5 private hospitals in the city of Shiraz, Iran. The survey probed into the practices adopted for the handling of needlesticks and sharps and the management of NSSIs. Randomization was used to select 9 out of 33 hospitals in Shiraz. These hospitals have a total of 1503 beds and accept 3666 outpatients and 1019 inpatients per day. A questionnaire was distributed amongst the selected hospitals and this was independently completed by the cohort of HCW. Out of 486 housekeeping workers in the selected hospitals, 92 workers were identified as being at risk of NSSI using the inclusion criteria of direct engagement in in the collection, handling and disposal of biomedical waste including the handling of sharps contaminated with blood. The questionnaire included 31 questions and was in the format of either multiple choice questions or free text. The questions revolved around:

- Workers educational and training conditions

- Awareness of the importance and hazards associated with medical waste

- Monitoring and training BMW management systems

- Vaccination of workers

- Workers reaction to NSSI

- Protective clothing
- Occurrence of sharps injuries in the past 12 months

- Workers beliefs about safety

- Workers knowledge of precautions

- Hospital placed precautionary measures against NSSIs

- The situation causing the NSSI

The characteristics of the occupational exposures were also asked, including the use of protective measures, immunization status and prophylactic management following the exposure. Two experts reviewed the initial questionnaire prior to a pilot sample being tested on 25 housekeeping workers.

To evaluate the questionnaire's reliability, $10 \%$ of participants were retested again 2 weeks later. The reliability of the questionnaire was confirmed by Cronbach's alpha calculation $(\alpha=0.87)$.

We obtained ethical approval from the Shiraz Medical Science University for data collection about biomedical waste management and workers knowledge and awareness about dangers associated with handling waste.

The answers regarding workers awareness were grouped into 'positive' and 'negative' responses.ve answers. The data was then coded, tabulated and analyzed using SPSS version 12 , Chi-square test, $\mathrm{T}$ - test and a $\mathrm{p}<0.05$ was considered statistically significant.

\section{Results}

$83.7 \%$ (77/92) of housekeeping workers had knowledge of the BMW system in their hospital. $79.2 \%(38 / 48)$ of Government hospital workers had knowledge of BMW management systems compared with $83.7 \%$ (39/44) of Private hospital workers. Government hospital workers knowledge of BMW management (mean =9.94) is significantly less than the Private hospitals workers (mean $=10.82$ ), $(\mathrm{t}=2.353, \mathrm{P}=0.021) .90 .2 \%$ (83/92) of housekeeping workers were aware of the dangers associated with waste, $87.5 \%$ ( 42/48) in government and 93/2\%( 41/44) in private hospitals. The data suggests that workers within the private sector appear to have superior training and education on BMW and associated hazards (Table 1).

In Table 2, precautions taken by the hospital workers in their BMW management efforts are shown in both the Government and the Private hospitals. The precautionary activities include such things as using protective clothing and equipment while handling the biomedical wastes. The incidence of NSSIs during one year prior to the survey among workers was $22.8 \%$ (21/92). The incidence was 31.3(15/48) for Government hospitals (educational hospitals), and $13.6 \%$ (6/44) for private hospitals. A statistically significant difference was found between the workers of the Private and Government hospitals in relation to NSSI $(\mathrm{p}=0.0444)$. As regards their knowledge of NSSI's, $83 / 7 \%$ of 92 respondents had attended 
Table 1 Housekeeping workers awareness with BMW

\begin{tabular}{|c|c|c|c|c|c|c|}
\hline \multirow[t]{2}{*}{ Workers awareness } & \multicolumn{2}{|c|}{ Government } & \multicolumn{2}{|c|}{ Private } & \multicolumn{2}{|c|}{ Total } \\
\hline & Yes & No & Yes & No & $\overline{\text { Yes }}$ & No \\
\hline $\begin{array}{l}\text { Awareness of dangers } \\
\text { associated with waste }\end{array}$ & $\begin{array}{c}42 \\
(87.5)\end{array}$ & $6(12.5)$ & $\begin{array}{c}41 \\
(93.2)\end{array}$ & $3(6.8)$ & $\begin{array}{c}83 \\
(90.2)\end{array}$ & $9(9.8)$ \\
\hline $\begin{array}{l}\text { Awareness of BMW } \\
\text { management }\end{array}$ & $\begin{array}{c}38 \\
(79.2)\end{array}$ & $\begin{array}{c}10 \\
(20.8)\end{array}$ & $\begin{array}{c}39 \\
(88.6)\end{array}$ & $5(11.4)$ & $\begin{array}{c}77 \\
(83.7)\end{array}$ & $\begin{array}{c}15 \\
(16.3)\end{array}$ \\
\hline $\begin{array}{l}\text { Training on BMW } \\
\text { management }\end{array}$ & $\begin{array}{c}36 \\
(75.0)\end{array}$ & $\begin{array}{c}12 \\
(25.0)\end{array}$ & $\begin{array}{c}41 \\
(93.2)\end{array}$ & $3(06.8)$ & $\begin{array}{c}77 \\
(83.7)\end{array}$ & $\begin{array}{c}15 \\
(16.3)\end{array}$ \\
\hline $\begin{array}{c}\text { Vaccination against tetanus } \\
\text { \&hepatitis }\end{array}$ & $\begin{array}{c}44 \\
(91.7)\end{array}$ & $4(8.3)$ & $\begin{array}{c}41 \\
(93.2)\end{array}$ & $3(6.8)$ & $\begin{array}{c}83 \\
(92.4)\end{array}$ & $7(7.6)$ \\
\hline $\begin{array}{l}\text { Workers satisfaction with } \\
\text { the present BMW system }\end{array}$ & $\begin{array}{c}35 \\
(72.9)\end{array}$ & $\begin{array}{c}13 \\
(27.1)\end{array}$ & $\begin{array}{c}40 \\
(90.9)\end{array}$ & $4(9.1)$ & $\begin{array}{c}75 \\
(81.5)\end{array}$ & $\begin{array}{c}17 \\
(18.5)\end{array}$ \\
\hline
\end{tabular}

Figures in parentheses are percentages.

educational programs on biomedical waste management and injury prevention at their hospital in the preceding year and $16.3 \%(15 / 92)$ were not trained in biomedical waste management $(\mathrm{P}=0.0379)$ with $88.9 \%$ having access to safety wear.

The training programs were conducted by the environmental health specialists and the infection control committees that work within the hospitals.

The data implies that workers in Government hospitals incur more needle stick injuries than those in the Private hospitals. This is most likely a result of a lack of worker awareness and knowledge, partially due to poor training and education programs.

When questioned about reporting NSSI's, procedures fed back by workers included reporting to supervisors, washing the injury site with soap and antiseptic, consulting with a doctor (and undergoing the appropriate

Table 2 Precautions taken by workers of BMW management

\begin{tabular}{cccc}
\hline Precautions workers took & Government & Private & Total \\
\hline $\begin{array}{c}\text { Put segrated waste in special waste } \\
\text { rooms }\end{array}$ & $6(12.5)$ & $2(4.5)$ & $8(8.7)$ \\
$\quad \begin{array}{c}\text { Wear gloves and masks } \\
\text { Wear gloves and masks and put } \\
\text { segregated wastes in trolleys for } \\
\text { transfer }\end{array}$ & $6(12.5)$ & $12(27.3)$ & $18(19.6)$ \\
$\begin{array}{c}\text { Wear gloves, masks and aprons } \\
\text { Regular washing of buckets and } \\
\text { wearing gloves and mask }\end{array}$ & $1(2.1)$ & $2(4.5)$ & $3(3.3)$ \\
Wear hand gloves and boots & $2(4.2)$ & $3(46.7)$ & $6(6.5)$ \\
$\begin{array}{c}\text { Put segregated waste in trolleys and } \\
\text { wear masks, gloves and aprons }\end{array}$ & - & $3(6.8)$ & $3(3.3)$ \\
$\begin{array}{c}\text { Wear protective clothing and careful } \\
\text { handling } \\
\text { All }\end{array}$ & $5(10.4)$ & $3(6.8)$ & $8(8.7)$ \\
Total & $1(2.1)$ & - & $1(1.1)$ \\
& $48(100.0)$ & $4(100.0)$ & $9(100.0)$ \\
\hline
\end{tabular}

Figures in parentheses are percentages. investigations), applying pressure to the injury site and receiving post-exposure vaccines. These procedures are often done in combination rather than individually. Of the 92 housekeeping workers, $8.7 \%(8 / 92)$ reported to supervisors, $1.1 \%(1 / 92)$ washed the wound with water, soap or antiseptics, $4.3 \%$ (4/92) consulted a doctor and provided blood samples for HIV or HBV in laboratory. $38 / 0 \%(35 / 90)$ carried out all the previously quoted procedures, $34.8 \%(32 / 92)$ had done all measures above and applied pressure to the wound site and $9.8 \%(9 / 92)$ had done all of the above and also received a vaccine. Only $3.39 \%$ (3/92) underwent all the stated procedures following NSSI. Procedures workers adopted in case of an injury are shown in Table 3.

Hospital workers should be vaccinated against Tetanus and Hepatitis B and of our cohort of 92, 92.4 \%( 85/92) had received both.

A number of limitations to the study can be identified. Firstly, the study concentrated on issues relating to NSSI's due to biomedical waste management only. The study can be further expanded by focusing on issues related to Hygiene, Environment, Sanitation, Health and Safety. The study was conducted on housekeeping workers who were directly engaged in collecting, handling and disposal of BMW in 9 hospitals within Shiraz. More representative and generalizable results would have been obtained if the sample was extracted from a larger cohort of workers.

\section{Discussions}

Needlestick injuries in HCWs are an important and significant occupational hazard and can potentially lead to infections with blood-borne pathogens such as HBV, $\mathrm{HCV}$, or HIV [15-18]. It is important to increase

Table 3 Procedures workers adopted in case of an injury

\begin{tabular}{lccc}
\hline $\begin{array}{c}\text { List of precautions workers } \\
\text { took }\end{array}$ & Government & Private & Total \\
\hline $\begin{array}{c}\text { Report to supervisors } \\
\begin{array}{c}\text { Wash injury site with soap } \\
\text { and betadine }\end{array}\end{array}$ & $4(8.3)$ & $4(9.1)$ & $8(8.7)$ \\
$\begin{array}{c}\text { Visit doctor and do some } \\
\text { tests }\end{array}$ & $4(8.3)$ & - & $1(1.1)$ \\
$\begin{array}{c}\text { Report to superisors, visit } \\
\text { doctors and do some tests }\end{array}$ & $21(43.8)$ & $14(31.8)$ & $35(38.0)$ \\
$\begin{array}{c}\text { Report to superisors, visit } \\
\text { doctors, do some tests and } \\
\text { press injury site }\end{array}$ & $7(14.6)$ & $25(56.8)$ & $32(34.8)$ \\
$\begin{array}{c}\text { Report to superisors, visit } \\
\text { doctors, do some tests and } \\
\text { inject vaccine }\end{array}$ & $8(16.7)$ & $1(2.3)$ & $9(9.8)$ \\
$\quad$ All & & & \\
$\quad$ Total & $3(6.3)$ & - & $3(3.39)$ \\
& $48(100)$ & $44(100)$ & $92(100)$ \\
\hline
\end{tabular}

Figures in parentheses are percentages. 
awareness around the prevalence and dangers of NSSI have in order to find alternative ways in which to reduce the incidence.

The present study describes the prevalence of NSSI amongst housekeeping workers involved in hospital BMW handling and disposal but also highlights the level of knowledge of these workers with regards to the public and environmental health implications of improper management of BMW.

The survey was carried out through an anonymous questionnaire and it focused on injuries caused by contaminated sharps, including needles, lancets, and scalpels. Within hospitals of Germany, a specialist consultant in emergency medicine is allocated and dedicated to reporting and managing occupational incidents such as NSSI as well as administering and advising on post-exposure prophylaxis [19]. The data of a Japanese teaching hospital also show a poor reporting rate of NSSI incident [20]. According to NHS policy in the UK, it is compulsory when staff sustain a needle-stick injury to report the incident [21]. However, evidence from the US suggests that more than half of all sharps-related injuries are not reported [22]. In our study, the infection committee receives only minimal reporting on NSSI's and reporting is not considered compulsory. Poor reporting of sharpsrelated injuries reveals a failure to appreciate the potential consequences of such injuries [14].

There are different strategies to prevent infections due to sharps injuries, including training HCWs and a reduction in unnecessary invasive procedures. Vaccination is one of the best ways to protect HCWs from infection, but vaccination is only available for HBV and Tetanus. In the present study, the number of vaccinated workers was $92.4 \%$. This figure would suggest that a greater awareness of the requirement of the HBV vaccination is required [23]. Many sharps injuries happened before and during sharps disposal, but were also due to unsafe sharps disposal boxes. These incidents would not have occurred if a safety device was used and the needle safety mechanism had been activated. These findings were supported by the results of recent studies in the USA, Canada, Japan, UK, and Germany [24-28].

This study has demonstrated that the inadequate reporting of NSSIs to medical staff was a common occurrence amongst health care workers. As many as two third of the survey participants did not seek medical treatment after an injury, which is a similar finding to studies carried out elsewhere $[8,29,30]$. The most common reasons for this are insufficient knowledge and poor practices. The observed high level of under-reporting suggests that workers need education on prevention, especially focusing on the importance of reporting all NSSI's and the possibilities of prophylaxis after exposure to BBP [31-33]. In our study all workers reported that the most common cause of injuries from needles in housekeeping workers was improper handling of needles, the use of overly full sharps containers and misplaced needle left by students or HCW's, especially within teaching hospitals. This echoes Bilsk et al, which reported that the most common cause of injuries from needles in nurses was improper handling of syringes and needles after injections (removing a needle from a syringe or placing the needle in a full container for medical waste) [34].

This study showed that adherence to the universal precautionary recommendations was another important factor in the prevention of NSSI's, a finding which is in accord with previous studies $[8,29,35]$. Given that safer sharps devices or devices with a built-in safety feature are not yet widely available in Iran, strengthening education and training systems is thus essential. This can be achieved through attendance at seminars designed to enhance awareness of the standard precautions and protocols, knowledge of which seems to be still far from adequate in Iran. As post exposure prophylaxis has been shown to be effective after these injuries [36], a system should be introduced to ensure that all health care workers have knowledge of appropriate means through which they can seek medical treatment and other follow up care following NSSI. The introduction of a system for the computerized collection of information in work is also required.

Reducing the risk of NSSIs through improved occupational health standards and safety management systems would ultimately decrease the burden of disease on society from infections with blood-borne pathogens in Iran as universal precautions play an important role in minimizing and preventing exposure of health care workers to such pathogens [37]. There is also a need to develop strategies to promote the use of universal precautions which take into account behavior change and accrual of knowledge including its integration into practice. Housekeeping workers are at high risk of NSSIs and hence BBP exposure and we recommend that they would benefit from a targeted education program about protective strategies against blood-borne infection. Iran needs an obligatory training programme in healthcare precautions, requiring involvement of senior health staff in the development and implementation of policies and systems for monitoring the appropriate use of equipment as well as establishing a post exposure reporting system.

\section{Competing interests}

The authors declare that they have no competing interests.

\section{Acknowledgements}

It would not have been possible to complete my research work without physical and unquantifiable moral support of Mysore university of India, medical science universities of Hormozgan and Shiraz, infection control committee members, environmental health experts and staff of Shiraz Hospitals. 


\section{Author details}

${ }^{1}$ Medical Record and Health Information Technology, Hormozgan University of Medical Science, Bandar Abbas 79168319, Iran. ${ }^{2}$ School of Health, Tehran University of Medical Sciences, Tehran, Islamic Republic of Iran. ${ }^{3}$ Obstetrics and Gynecology, North Bristol NHS, Becks pool Road, Frenchay Bristol, Bs161JE, United Kingdom.

\section{Authors' contributions}

PL conducted the statistical analysis, interpreted the data, drafted the manuscript, and critically revised the manuscript for intellectual content. FE supported the data collection; critically revised the manuscript.HK critically revised the manuscript. All authors read and approved the final manuscript.

Received: 11 February 2012 Accepted: 18 May 2012

Published: 7 June 2012

\section{References}

1. Pruss-Ustun A, Rapiti E, Hutin Y: Estimation of the global burden of disease attributable to contaminated sharps injuries among health-care workers. Am J Ind Med 2005, 48(6):482-490.

2. National Institute for Occupational Safety and Health: NIOSH Alert: preventing needlestick injuries in health care settings [DHHS (NIOSH) Publication No. 2000-108]. Cincinnati, OH: U.S. Department of Health and Human Services; 1999.

3. Ilyas M: Hospital and Biomedical Waste Management. Community Medicine \& Public Health. 5th ed. Karachi: Time Publishers; 2000:621-623.

4. Park K: Hospital Waste Management. Park's Textbook of Preventive and Social Medicine. 18th ed. India: Banarsidas Bhanot; 2007:596.

5. Yacoub R, Al Ali R, Moukeh G, Lahdo A, Mouhammad Y, Nasser M: Hepatitis $B$ vaccination status and needlestick injuries among healthcare workers in Syria. J Glob Infect Dis 2010, 2(1):28-34.

6. Sharps injury information. [http://www.isips.org/sharps.shtml]

7. World Health Organization: The world health report: 2002: Reducing risks, promoting healthy life. Geneva: World Health Organization; 2002

8. Kakizaki M, Ikeda N, Ali M, Enkhtuya B, Tsolmon M, Shibuya K, Kuroiwa C: Needlestick and sharps injuries among health care workers at public tertiary hospitals in an urban community in Mongolia. BMC Res Notes 2011, 14(4):184.9.

9. Norsayani MY, Noor Hl: Study on incidence of needle stick injury and factors associated with this problem among medical students. $J$ Occup Health 2003, 45(3):172-178

10. Jovic-Vranes A, Jankovic S, Vranes B: Safety practice and professional exposure to blood and blood-containing materials in serbian health care workers. J Occup Health 2006, 48(5):377-382.

11. Trim JC, Elliott TS: A review of sharps injuries and preventative strategies. J. Hosp. Infect 2003, 53(4):237-242.

12. Centers for Disease Control and Prevention: Sharps injury prevention workbook: workbook for designing, implementing, and evaluating a sharps injury prevention program; 2008. [http://www.cdc.gov/sharpssafety] website.

13. CfDCa P: Overview: Risks and Prevention of Sharps Injuries in Healthcare Personnel. Atlanta, Ga, USA: CDC; 2004

14. Azadi A, Anoosheh M, Delpisheh A: Frequency and barriers of underreported needlestick injuries amongst Iranian nurses, a questionnaire survey. Journal of Clinical Nursing 2011, 20:488-493.

15. Pellissier $G$, Miguéres $B$, Tarantola A: Risk of needlestick injuries by injection pens. J Hosp Infect 2006, 63:60-64.

16. Saberi Firoozi M, Serati AR, Gholamzadeh S: The long-term immunity among health care workers vaccinated against hepatitis B virus in a large referral hospital in southern Iran. Arch Iran Med 2006, 9(3):204-207.

17. Sadoh WE, Fawole AO, Sadoh AE, Oladimeji AO, Sotiloye OS: Practice of universal precautions among health care workers. J Natl Med Assoc 2006, 98(5):722-726

18. Smith DR, Wei N, Zhang YJ, Wang RS: Needlestick and sharps injuries among a cross-section of physicians in Mainland China. Am J Ind Med 2006, 49:169-174.

19. Wicker S, Jung J, Allwinn R, Gottschalk R, Rabenau HF: Prevalence and prevention of needlestick injuries among health care workers in a German university hospital. Int Arch Occup Environ Health 2008, 81(3):347-354.

20. Smith DR, Mihashi M, Adachi Y, Nakashima Y, Ishitake T: Epidemiology of needlestick and sharps injuries among nurses in a Japanese teaching hospital. J Hosp Infect 2006, 64:44-49.
21. Adams S, Stojkovic G, Leveson SH: Needlestick injuries during surgical procedures: a multidisciplinary online study. Occup Med 2010, 60(2):139-144.

22. Prevention CfDCa: Overview: Risks and Prevention of Sharps Injuries in Healthcare Personnel. CDC, Atlanta, Ga, USA; 2004

23. Wijk van PTL, Pelk-Jongen M, de Boer E, Voss A, Wijkmans C, Schneeberger PM: Differences between hospital- and community- acquired blood exposure incidents revealed by a regional expert counseling center. Infection 2006, 34 (1):17-21.

24. Tuma S, Sepkowitz KA: Efficacy of safety-engineered device implementation in the prevention of percutaneous injuries: a review of published studies. Clin Infect Dis 2006, 42(8):1159-1170.

25. Suzuki R, Kimura S, Shintani Y: The efficacy of safety winged steel needles on needlestick injuries. Kansenshogaku Zasshi 2006, 80(1):39-45.

26. Visser L: Toronto hospital reduces sharps injuries by $80 \%$, eliminates blood collected injuries. A case study: Toronto east general hospital pioneers healthcare worker safety. Healthc Q. 2006, 9(1):68-70.

27. Clarke SP, Sloane DM, Aiken LH: Effects of hospital staving and organizational climate on needlestick injuries to nurses. Am J Public Health 2002, 92(7):1115-1119.

28. Adams D, Eliott TSJ: Impact of safety needle devices on occupationally acquired needlestick injuries: a four-year prospective study. J Hosp Infect 2006, 64:50-55.

29. Smith DR, Mihashi M, Adachi, Shouyama Y, Mouri F, Ishibashi N, Ishitake T: Organizational climate and its relationship with needlestick and sharps injuries among Japanese nurses. Am J Infect Control 2009, 37(7):545-550.

30. Makary MA, Al-Attar A, Holzmueller CG, Sexton JB, Syin D, Gilson MM, Sulkowski MS, Pronovost PJ: Needlestick injuries among surgeons in training. N Engl J Med 2007, 356(26):2693-2699.

31. Kohn WG, Collins AS, Cleveland JL, Harte JA, Eklund KJ, Malvitz DM: Guidelines for infection control in dental health-care settings-2003. MMWR Recomm Rep 2003, 52:1-61.

32. Hutin YJ, Hauri AM, Armstrong GL: Use of injections in healthcare settings worldwide, 2000: Literature review and regional estimates. BMJ 2003, 327:1075.

33. Askarian M, Ghavanini AA: Survey on adoption of measures to prevent nosocomial infection by anaesthesia personnel. East Mediterr Health J 2002, 8:416-421.

34. Bilski B: Needlestick injuries in nurses- the Poznan study. Int J Occup Med Environ Heaith 2005, 18:251-254.

35. Gershon RRM, Pearson JM, Sherman MF, Samar SM, Canton AN, Stone PW: The prevalence and risk factors for percutaneous injuries in registered nurses in the home health care sector. Am J Infect Control 2009, 37(7):525-533.

36. Pruss-Ustun A, Rapiti E, Hutin Y: Sharps injuries: Global burden of disease from sharps injuries to health-care workers (WHO Environmental burden of disease series, No.3). Geneva: World Health Organization; 2003

37. Motamed N, Farhang B, Mahmoodi F, Khalilian A, Heirati M, Nozari M: Knowledge and practices of health care workers and medical students towards universal precautions in hospital in Mazandaran Province. Eastern Mediterranean Health Journal 2006, 12:653-661.

\section{doi:10.1186/1756-0500-5-276}

Cite this article as: Lakbala et al:: Needlestick and sharps injuries among housekeeping workers in hospitals of Shiraz, Iran. BMC Research Notes 2012 5:276

\section{Submit your next manuscript to BioMed Central and take full advantage of:}

- Convenient online submission

- Thorough peer review

- No space constraints or color figure charges

- Immediate publication on acceptance

- Inclusion in PubMed, CAS, Scopus and Google Scholar

- Research which is freely available for redistribution 